\title{
Prinsip Pembangunan Infrastruktur yang Berlandaskan Hak Asasi Manusia Terhadap Eksistensi Masyarakat Hukum Adat di Indonesia
}

\author{
Raden Muhammad Arvy Ilyasa \\ Fakultas Hukum Universitas Negeri Semarang, Semarang, Indonesia \\ E-mail: rmuhammadarvy123@gmail.com
}

\begin{tabular}{l}
\multicolumn{1}{c}{ Dikirim: $28 / 05 / 2020$} \\
\hline Info Artikel \\
\hline Keywords: \\
Infrastructur \\
Development; \\
Indigenous People; \\
Human Right. \\
\\
\\
Kata Kunci: \\
Pembangunan \\
Infrastruktur; \\
Masyarakat Adat; \\
Hak Asasi Manusia. \\
\end{tabular}

\section{Abstract}

Infrastructure development can simplify the flow of the economy and provide accessibility for the community to reach public facilities that have been provided. This study aims to examine the problem of infrastructure development in Indonesia, which often occurs in conflicts between indigenous peoples and the government regarding land for infrastructure development on the ulayat lands of indigenous peoples. The research method used normative research with an statute approach, conceptual approach and analyzed descriptively qualitatively. The results show that in infrastructure development in Indonesia, several aspects must be considered, such as the balance of development and the interests of the community, paying attention to aspects of human rights so that this does not happen. One suitable concept is Free Prior Informed and Consent (FPIC) as a form of recognition of the existence of indigenous peoples as the subject of development, not as objects of development.

\begin{tabular}{l}
\hline Abstrak \\
\hline Pembangunan infrastruktur dapat mempermudah arus ekonomi serta \\
memberikan aksesibilitas kepada masyarakat untuk menjangkau \\
fasilitas-fasilitas publik yang sudah di sediakan. Penelitian ini bertujuan \\
untuk mengkaji persoalan pembangunan infrastruktur di Indonesia yang \\
sering kali terjadi konflik agraria antara masyarakat adat dengan pihak \\
pemerintah terkait dengan lahan untuk pembangunan infrastruktur \\
berada pada tanah ulayat masyarakat hukum adat. Metode penelitian \\
menggunakan penelitian normatif dengan pendekatan perundang- \\
undangan (statute approach) dan pendekatan konseptual (conceptual \\
approach) serta dianalisis secara deskriptif kualitatif. Hasil penelitian \\
menunjukan bahwa dalam pembangunan infrastruktur di Indonesia \\
harus mempertimbangkan beberapa aspek seperti keseimbangan \\
pembangunan dan kepentingan masyarakat, memperhatikan aspek- \\
aspek Hak Asasi Manusia agar tidak terjadi pelanggaran. Salah satu \\
konsep yang sesuai adalah Free Prior Informed and Consent (FPIC)
\end{tabular}




\section{A. PENDAHULUAN}

Tanah merupakan salah satu komponen ekosistem yang sangat strategis bagi kelangsungan hidup umat manusia, dan juga sebagai faktor utama dalam setiap kegiatan pembangunan infrastruktur ${ }^{1}$.

Infrastruktur memegang peranan penting dalam suatu Negara. Pembangunan infrastruktur menjadi roda penggerak pertumbuhan ekonomi dan pembangunan suatu bangsa. Keberadaan sarana dan prasarana fisik atau dikenal sebagai infrastuktur menjadi bagian penting dalam usaha pemenuhan kesejahteraan. Mulai dari transportasi jalan, bandara, pelabuhan, waduk, dll. Sesuai dengan amanat Pasal 33 Undang-Undang Dasar 1945 tercantum dasar demokrasi ekonomi yaitu untuk kemakmuran masyarakat bukan perseorang saja, serta berlandaskan semangat sosial dan menempatkan penguasaan terhadap berbagai sumber daya untuk kepentingan publik. Pengaturan ini berdasarkan anggapan bahwa Negara adalah pemegang mandat untuk melaksanakan kehidupan kenegaraan di Indonesia yang menguasai sumber daya alam untuk dipergunakan sebesar-besarnya bagi kemakmuran rakyat. Lalu pertanyaan muncul apakah pembangunan infrastruktur pada saat ini dengan tujuan utama untuk kepentingan masyarakat atau pihak lain?

Pada masa pemerintahan yang sekarang lebih memprioritaskan pembangunan infrastruktur untuk meningkatkan daya saing dalam lingkup nasional dan sebagai upaya untuk pemerataan di setiap daerahnya serta mengurangi disparitas antar daerah. Masifnya pembangunan infrastruktur yang dilakukan oleh pemerintahan sekarang bukan tanpa adanya masalah. Dalam proses pembangunan infrastruktur pemerintah sering mengalami konflik agraria dengan masyarakat pada umumnya, seperti pada proyek pembangunan Bandara Internasional Kulonprogo di Yogyakarta dengan petani dikarenakan lahan tempat Bandara akan didirikan adalah lahan produktif bagi para petani sehingga berujung konflik serta kriminalisasi dan tindak kekerasan kepada warga, selain di Yogyakarta masyarakat lokal di Bandara Dominique Edward Osok di Sorong, Papua juga mengalami hal yang sama hingga harus tergusur dari tanahnya sendiri ${ }^{2}$. Konflik agraria juga di alami oleh masyarakat adat, terhitung pada tahun 2018 terdapat 326 konflik sumber daya alam dan agraria di seluruh Indonesia yang melibatkan areal seluas 2.101.858 hektar dengan korban total mencapai 186.631 jiwa dari total korban itu, 176.637 di antaranya berasal dari masyarakat adat. Data tersebut menjadikan masyarakat adat sebagai salah satu pihak yang paling rentan dalam masalah konflik agraria ${ }^{3}$.

Kasus yang dialami oleh masyarakat adat justru bertentangan dengan Negara yang harusnya mengakui tentang eksistensi masyarakat adat di Indonesia melalui amanat pasal $18 \mathrm{~B}$ ayat 2 yaitu:

1 Hetharie, Y. (2019). "Perjanjian Nominee sebagai Sarana Penguasaan Hak Milik atas Tanah oleh Warga Negara Asing (WNA) Menurut Kitab Undang-Undang Hukum Perdata”, SASI, 25 (1): 27-36. DOI: https://doi.org/10.47268/sasi.v25i1.147, h. 27.

2 Zuhra, W. U. N. Proyek Infrastruktur Jokowi Biang Konflik Agraria. Available from https://tirto.id/proyek-infrastruktur-jokowi-jadi-biang-konflik-agraria-b5yx. (Diakses 20 Mei 2020)

3 Novelino, A. Ribuan orang masyarakat adat Jadi Korban Konflik Agraria. Available from https://www.cnnindonesia.com/nasional/20190117042203-12-361437/ribuan-orang-masyarakat-adat-jadikorban-konflik-agraria. (Diakses 20 Mei 2020) 
"Negara menghormati dan mengakui kesatuan-kesatuan masyarakat hukum adat serta hak-hak tradisionalnya sepanjang masih hidup dan sesuai dengan perkembangan masyarakat dan prinsip Negara Kesatuan Republik Indonesia yang diatur dalam undang-undang”.

Sebagai salah satu landasan deklaratif bahwa Negara mengakui dan menghormati keberadaan dan hak-hak masyarakat hukum adat. Terjadinya konflik yang berujung pada kriminalisasi warga setempat serta kekerasan yang terjadi membuat seolah-olah Negara sebagai pelaku pelanggaran HAM yang justru seharusnya melindungi hak asasi manusia tiap warga negaranya sesuai dengan amanat pasal 28A sampai $28 \mathrm{~J}$ yang tentang hak asasi manusia pada undang-undang dasar 1945. Hak asasi manusia merupakan suatu hak yang dimiliki karena ia adalah manusia, bukan karena diberikan tetapi ada karena kodratnya sebagai seorang manusia, oleh karena itu Negara dalam menjalankan pembangunan infrastruktur harus memperhatikan prinsip hak asasi manusia serta memperhatikan eksistensi masyarakat adat beserta haknya yang melekat.

Wacana pemenuhan prinsip Free Prior Consent (FPIC), suatu konsep bahwa masyarakat adat memiliki hak tanpa ada tekanan untuk menyatakan persetujuan maupun ketidaksetujuan mereka atas rencana proyek pembangunan maupun suatu investasi yang bersinggungan dengan tanah adat mereka yang dapat menimbulkan kerugian. FPIC bukanlah suatu konsep baru dimana dapat ditemukan dalam deklarasi PBB. Dimasukkannya FPIC mengenai tentang hak-hak masyarakat adat (United Nations Declaration on the Rights of Indegenous Peoples) yang disahkan pada tahun 2007. Contoh pemenuhan prinsip FPIC yang pernah terjadi yaitu pada pembangunan perkebunan kelapa sawit dimana telah mendapatkan dukungan dari Roundtable Sustainable Palm Oil atau (RSPO), dimana FPIC ini sebagai suatu dasar persetujuan yang adil bagi masyarakat setempat dan perusahaan maupun pemerintah itu sendiri, dikembangkan dengan cara memastikan bahwa hukum maupun hak masyarakat hukum adat terjamin dan dihormati serta memastikan bagaimana negosiasi yang terjadi berlangsung sesuai dengan hukum dan aturan yang sudah disepakati oleh pihak yang terlibat. $^{4}$

Berdasarkan uraian di atas penulis tertarik untuk mengkaji permasalahan yang ada, yaitu bagaimana pengakuan terhadap eksistensi masyarakat hukum adat di Indonesia dan bagaimana seharusnya Negara memposisikan diri apabila berkaitan dengan menjalankan pembangunan infrastruktur untuk kepentingan umum tetapi beroritentasi kepada HAM sebagai wujud keberpihakan kepada masyarakat hukum adat.

\section{B. METODE PENELITIAN}

Pada penulisan ini menggunakan metode penelitian hukum yuridis normatif. Untuk mendapatkan data dalam penelitian hukum ini, penulis menggunakan beberapa pendekatan yaitu pendekatan undang-undang (statute approach), pendekatan kasus (case approach), dan juga menggunakan pendekatan komparatif (comparative approach) ${ }^{5}$. Penelitian ini menggunakan penelian pustaka denngan mendapatkan data sekunder berupa buku literatur, hasil penelitian, jurnal, artikel, maupun peraturan hukum terkait dengan objek penelitian yaitu perihal pembangunan infrastruktur, hak asasi manusia, dan masyarakat hukum adat ${ }^{6}$.

${ }^{4}$ Ikbal, I. (2015). "Prinsip Free Prior Informed Consent Terhadap Perlindungan Masyarakat Hukum Adat Atas Tanah Adat Dalam Perspektif Hukum Hak Asasi Manusia Internasional”, Fiat Justicia: Jurnal Ilmu Hukum, 6 (3): 1-16, h. 3

5 Marzuki, P. M. (2005). Penelitian Hukum, Jakarta: Media Group, h. 20

6 Ibid. 


\section{PEMBAHASAN}

\section{Pengakuan Eksistensi Masyarakat Hukum Adat di Indonesia}

Persebaran masyarakat adat di Indonesia telah muncul sejak lama sebelum munculnya peradaban maju yang kita kenal saat ini. Berbagai macam istilah muncul untuk mendeskripsikan masyarakat adat seperti masyarakat hukum adat, masyarakat tradisional, kesatuan masyarakat hukum adat, masyarakat adat yang terpencil, komunitas masyarakat, komunitas adat terpencil, dan istilah lainnya. Di dalam bukunya yang berjudul Beginselen en Stelsel van bet Adatrecht, Ter Haar merumuskan masyarakat hukum adat sebagai kelompok- kelompok tertentu yang sifatnya ajek dengan pemerintahan sendiri yang memiliki benda-benda materiil maupun immaterial ${ }^{7}$

Kesatuan masyarakat ini merupakan sebuah kelompok masyarakat yang teratur yang bertingkah laku sebagai sebuah kesatuan, mempunyai penguasa adat, menetap disuatu daerah tertentu, mempunyai kekayaan adat masing-masing, serta memiliki hukum adat masing-masing. Pengertian masyarakat adat dan masyarakat hukum adat berbeda karena masyarakat adat merujuk pada masyarakat tertentu dengan dengan ciri-ciri tertentu, sedangkan pengertian masyarakat hukum adat adalah merujuk pada kelompok masyarakat yang hidup di suatu wilayah (ulayat) atau lingkungan hidup tertentu, memiliki kekayaan tersendiri serta pemimpin yang bertugas menjaga kepentingan kelompok. Istilah masyarakat hukum adat dilahirkan dan digunakan oleh pakar hukum adat yang lebih banyak difungsikan dalam keperluaan teoritik akademis sedangkan masyarakat adat digunakan oleh kalangan non hukum yang bersumber dari berbagai macam kesepakatan Internasional ${ }^{8}$.

Menurut F.D. Holleman (sependapat dengan Van Vollenhoven) hukum adat adalah norma-norma hukum, norma-norma hidup yang disertai dengan saksi dan jika perlu dapat dipaksakan oleh masyarakat atau badan-badan yang bersangkutan supaya diturut dan dihormati oleh para warganya tanpa memperdulikan ada atau tidaknya keputusan petugas hukum. Menurut Logemann hukum adat adalah norma-norma hidup, norma-norma pergaulan hidup bersama yaitu peraturan-peraturan tingkah laku yang harus diikuti oleh segenap warga pergaulan hidup bersama yang memiliki sanksi berupa sanksi ringan maupun sanksi berat disebut sebagai norma hukum ${ }^{9}$. Masyarakat hukum adat dan hukum adat lahir dan ada telah ada jauh sekali sebelum berdirinya Negara Kesatuan Republik Indonesia itu ada, oleh karena itu seharusnya pemerintah mengakui eksistensi masyarakat adat beserta hak-hak yang dimilikinya sesua dengan prinsip pendirian Negara dengan wujud peraturan normatif yaitu perundang-undangan. Dalam Undang-Undang 1945 mengatur keberadaan masyarakat hukum adat sebagai suatu subjek hukum yang berbeda dengan subjek hukum lainnya. Pada periode pertama bagian penjelasan UUD 1945 terdapat penjelasan mengenai Persekutuan Hukum Rakyat yaitu masyarakat hukum adat yang keberadaannya sudah ada sebelum proklamasi Republik Indonesia. Dalam peraturan lain terkait mengenai eksistensi masyarakat hukum adat dapat ditemukan dalam:

a) Pasal 18 B ayat 2 Undang-Undang Dasar 1945

Negara mengakui dan menghormati kesatuan-kesatuan masyarakat hukum adat beserta hak tradisionalnya sepanjang masih hidup dan sesuai dengan perkembangan masyarakat dan prinsip Negara Kesatuan Republik Indonesia yang diatur dalam undang-undang. Pasal ini menjadi pengakuan secar deklaratif bahwa Negara mengakui dan menghormati keberadaan beserta hak-hak masyarakat adat dengan persyaratan:

1) Sepanjang masih hidup

\footnotetext{
7 Soekanto, S. (2016). Hukum Adat Indonesia, Jakarta: Rajawali Pers, h. 34

8 Isfardiyana, S. H. (2018). Hukum Adat, Yogyakarta, UII Press Yogyakarta, h. 75-76

9 Ibid, h. 16
} 
2) Sesuai dengan perkembangan masyarakat

3) Sesuai dengan prinsip Negara Kesatuan Republik Indonesia

4) Diatur dalam undang-undang

b) Pasal 28 ayat 3 UUD 1945

Identitas budaya dan masyarakat tradisional dihormati selaras dengan perkembangan jaman dan peradaban.

c) Pasal 32 ayat 1 dan 2 UUD 1945

1) Ayat 1

Negara memajukan kebudayaan nasional Indonesia ditengah peradaban dunia dengan menjamin kebebasan masyarakat dalam memelihara dan mengembangkan nilai budayanya

2) Ayat 2

Negara menghormati dan memelihara Bahasa daerah sebagai kekayaan budaya nasional

Pengaturan mengenai masyarakat adat dan hak-hak tradisionalnya dibawah konsep pengakuan terbatas dapat ditemui pad UU Kehutanan (Undang-Undang No.41 tahun 1999). Beberapa pasal yang mengatur terkait dengan eksistensi masyarakat adat dapat di temui dalam pasal 4 ayat 3 dan pasal 67. Pasal 4 ayat 3 Undang-Undang Kehutanan menyebutkan Penguasaan hutan oleh Negara tetap memperhatikan hak masyarakat hukum adat, sepanjang kenyataannya masih ada dan diakui keberadaannya, serta tidak bertentangan dengan kepentingan nasional. Dalam pasal 67 Undang-Undang Kehutanan menyebutkan:

a) Masyarakat adat menurut kenyataannya masih ada dan diakui keberadaannya berhak untuk:

1) Melakukan pemungutan hasil hutan untuk pemenuhan kebutuhan hidup seharihari masyarakat adat yang bersangkutan

2) Melakukan kegiatan pengelolaan hutan berdasarkan hukum adat yang berlaku dan tidak bertentangan dengan Undang-Undang

3) Mendapatkan pemberdayaan dalam rangka peningkatan kesejahteraannya

b) Pengukuhan dan hapusnya keberadaan masyarakat adat sebagaimana dimaksud ayat 1 ditetapkan dengan Peraturan Daerah

c) Ketentuan lebih lanjut sebagaimana dimaksud pada ayat 1 dan ayat 2 diatur dengan pemerintah

Penjelasan pasal 67 lebih jauh menyebutkan pada Ayat 1 bahwa Masyarakat hukum adat diakui keberadaannya jika memenuhi persyaratan yaitu:

a) Masyarakat masih dalam bentuk paguyuban (rechtsgemeenschap)

b) Ada kelembagaan dalam bentuk perangkat penguasa adatnya

c) Ada wilayah hukum adat yang jelas

d) Ada pranata dan perangkat hukum khususnya peradilan adat yang masih ditaati

e) Masih mengadakan pemungutan hasil hutan di wilayah hutan sekiatnya untuk pemenuhan kebutuhan hidup sehari-hari.

Jika dilihat dari Undang-Undang Kehutanan mengenai eksistensi masyarakat adat dijelaskan bahwa kehadiran masyarakat adat diakui keberadaanya jika ada ketetapan mengenai Peraturan Daerah sesuai dengan kriteria yang dijelaskan pada pasal 67 ayat 1 . Serta keberadaan masyarakat adat tidak boleh bertentangan dengan kepentingan nasional jika dilihat pada pasal 4 ayat 3 apabila belum ada Undang-Undang khusus yang mengaturnya. Peraturan diatas terkait dengan kehadiran masyarakat adat memiliki persamaan pengakuan yaitu diakui keberadaannya selama tidak bertentangan dengan perundang-undangan dan 
kepentingan nasional ${ }^{10}$. Jika dilihat dalam konteks hukum agraria terkait dengan masyarakat hukum adat terdapat dalam Undang-Undang No.5 Tahun 1960 tentang Peraturan Dasar Pokok-Pokok Agraria (UUPA) dalam pasal 2 ayat (4) bahwa pelaksanaan hak menguasai dari Negara dalam pelaksanaannya bisa dikuasakan kepada daerah-daerah swantran dan masyarakat hukum adat. Jika dilihat dalam pasal ini maka masyarakat adat dapat dilimpahkan penguasaan atas tanah yang dikuasai langsung oleh Negara, penguasaannya dapat dilimpahkan kepada masyarakat adat dengan tujuan untuk kemakmuran.

\section{Sengketa Tanah Ulayat Masyarakat Hukum Adat di Indonesia}

Tanah bagi kehidupan manusia mempunyai kedudukan yang sangat penting. Hal ini disebabkan hampir seluruh aspek kehidupannya terutama bagi bangsa Indonesia tidak dapat terlepas dari keberadaan tanah yang sesungguhnya tidak hanya dapat ditinjau dari aspek ekonomi saja, melainkan meliputi segala kehidupan dan penghidupannya. ${ }^{11}$

Tanah sebagai karunia Tuhan Yang Maha Esa kepada umat manusia merupakan faktor yang penting dalam peradaban manusia.Tanah memiliki nilai ekonomis yang dapat digunakan untuk produksi, dapat mendatangkan kesejahteraan serta sebagai bentuk warisan. Karena pentingnya tanah maka setiap orang berusaha untuk memiliki dan menguasainya. Oleh karena itu Negara merumuskan terkait dengan tanah dan sumber daya alam pada Undang-Undang Dasar 1945 pasal 33 ayat (3). Hal ini menjelaskan bahwa Negara memiliki tanggung jawab terkait dengan pengelolaan sumber daya alam dalam hal ini tanah agar dapat dipergunakan secara adil dan mendatangkan kesejahteraan bagi masyarakat. Namun amanat diatas berbanding terbalik dengan kenyataan, karena di Indonesia ketimpangan yang menimbukan sengketa terkait dengan tanah masih bersinggungan dengan aspek pembangunan infrastruktur.

Konsep penguasaan tanah dalam masyarakat hukum adat berdasarkan hak ulayat. Secara yuridis hak ulayat adalah suatu hak yang melekat pada kompetensi ciri khas yang ada pada masyarakat hukum adat berupa kewenangan maupun kekuasaan untuk mengurus dan mengatur rentang tanah dan tanamannya dengan berlaku ke dalam maupun ke luar masyarakat hukum adat dan merupakan hak yang mutlak (absolut). Hak ulayat merupakan serangkaian wewenang dan kewajiban suatu masyarakat hukum adat yang merupakan hubungan dengan tanah yang terletak dalam wilayahnya. Hak ulayat memiliki dua unsur yaitu: ${ }^{12}$

a) Unsur kewenangan termasuk dalam bidang hukum perdata

b) Unsur kewenangan yang mengatur penguasaan dan memimpin penggunaan tanah bersama yang termasuk dalam bidang hukum publik dan pelaksanaannya dilimpahkan kepada kepala persekutuan atau bersama dengan tokoh persekutuan lainnya.

Menurut ketentuan dan kriteria UUPA masih ada masyarakat adat dan masih berlangsung hak ulayat meliputi unsur-unsur:

a) Masyarakat hukum adat

b) Wilayah tempat hak ulayat berlangsung

c) Hubungan keterikatan dan ketergantungan masyarakat hukum adat dengan wilayahnya

\footnotetext{
10 Agus, A. A. (2017). "Eksistensi Masyarakat Adat Dalam Kerangka Negara Hukum di Indonesia”, Jurnal Sosialisasi Pendidikan Sosiologi, 5-15, h. 9-10

11 Laturette, A. I. (2016). "Penyelesaian Sengketa Hak Atas Tanah Masyarakat Hukum Adat", SASI, 22 (2) : 52-66. DOI: https://doi.org/10.47268/sasi.v22i2.168, h. 52.

12 Kusumaatmadja, M. (2003). Konsepsi Hukum Negara Nusantara Pada Konfrensi Hukum Laut, Bandung: Alumni, h. 17
} 
d) Adanya kewenangan untuk mengatur secara bersama-sama pemanfaatan tanah, perairan, tanaman, serta binatang-binatang yang ada di wilayah hukum adat yang masih berlaku ${ }^{13}$.

Walaupun sudah diatur sedemikian rupa tetapi fenomena yang terjadi saat ini terkait dengan sengketa tanah antar masyarakat maupun dengan pemerintah. Masing-masing pihak mengklaim kepemilikan tanah, hal itulah yang mengakibatkan terjadinya perlawanan masyarakat hukum adat dengan pemerintah. Sengketa yang terjadi bisa berupa sengketa pidana, sengketa perdata, sengketa administratif, dan sebagainya. Terkait dengan kasus seputar tanah adat di Indonesia banyak sekali terjadi, salah satunya adalah di Dayak. Masyarakat keturunan Dayak Meratus yang tinggal di sepanjang lereng Pegunungan Meratus, berencana berunjuk rasa ke Kantor Dewan Perwakilan Rakyat Daerah Kabupaten Tanah Bumbu, Kalimantan Selatan, Selasa, 25 April 2017. Koordinator aksi demontrasi, Miso, mengatakan masyarakat Dayak Meratus mendesak Pemerintah Daerah dan DPRD Tanah Bumbu serius membela hak-hak ulayat masyarakat adat dayak. Dalam aksi tersebut menyuarakan empat tuntutan. Pertama, Dayak Meratus mendesak Pengadilan Negeri Batulicin membebaskan aktivis AMAN Kabupaten Tanah Bumbu bernama Trisno Susilo dan Manasse Boekit dari jeratan pidana. Kedua, Miso mendesak pemerintah daerah menghentikan aksi perusahaan yang merampas tanah adat milik Dayak Meratus. Tuntutan ketiga dari Dayak Meratus mendesak kepolisian mengusut tuntas kelakuan perusahaan yang merampas tanah adat di sekitar lereng Pegunungan Meratus. Adapun tuntutan keempat mendesak pemerintah daerah dan DPRD memberikan pengakuan tanah adat Dayak Meratus lewat peraturan daerah. ${ }^{14}$

Masalah sengketa tanah adat juga terjadi dalam sektor pembangunan infrastruktur. Ketua Komnas HAM Ahmad Taufan Damanik mengatakan, setiap pembangunan infrastruktur, baik itu jalan tol, bandara, pelabuhan, pembangkit listrik tenaga uap, waduk, dan sebagainya pasti membutuhkan lahan yang tidak kecil. Lahan, khususnya di Pulau Jawa, yang sudah sempit semakin terjepit oleh kebutuhan lahan untuk berbagai proyek infrastruktur, setidaknya ada sekitar 269 proyek infrastruktur, yang dibingkai dalam Proyek Strategis Nasional, yang diatur di dalam Peraturan Presiden No 3/2016 sebagaimana diubah dalam Perpres No 58/2017. ${ }^{15}$ Persoalan ini terjadi dalam ranah pembangunan infrastruktur yang harusnya membawa pengaruh positif bagi masyarakat justru kenyataanya berbeda karena ada konflik kepentingan dimana pemerintah lebih mengutamakan kepentingan nasional, serta pengakuan atas masyarakat hukum adat diakui apabila tidak bertentangan dengan kepentingan bangsa dan perundang-undangan. Dapat ditafsirkan bahwa selama kepentingan bangsa hadir maka hak masyarakat hukum adat dapat dipinggirkan, oleh karena itu dibutuhkan strategi pembangunan yang berorientasi kepada kesejahteraan dengan memperhatikan HAM masyarakat hukum adat agar tidak terjadi lagi pelanggaran HAM.

\section{Prinsip Pembangunan Infrastruktur yang Berlandaskan HAM}

Permasalahan seputar pembangunan dalam hal ini pembangunan infrastruktur terkait dengan penegakan HAM dinilai menjadi sangat serius dan mendesak. Tantangan yang dihadapi terkait dengan persoalan HAM yang terjadi dalam lingkup pembangunan yang

13 Isfardiyana, S.H. Op.Cit., h. 124

14 Ravelo, C. Sengketa Tanah Adat, Warga Dayak Meratus Demo DPRD Tanah Bumbu. Available from https://nasional.tempo.co/read/869075/sengketa-tanah-adat-warga-dayak-meratusdemo-dprd-tanahbumbu/full\&view=ok. (Diakses 22 Mei 2020).

15 Yakur, A.S. Sengketa Agraria Meningkat di Duga Dampak Pembangunan Infrastruktur yang Masif. Available from https://www.hidayatullah.com/berita/nasional/read/2018/01/24/133768/sengketa-agrariameningkat-diduga-dampak-pembangunan-infrastruktur-masif.html. (Diakses 22 Mei 2020). 
sering kali terjadi berbagai tindakan represif pemerintah. Pandangan sebagian orang yang menganggap bahwa HAM merupakan suatu hal atau konsep yang merugikan serta menghalangi proses pembangunan yang terjadi. Muncul kontradiksi tersendiri apabila berbicara mengenai permasalahan ini karena bagi pihak yang mengedepankan HAM justru dianggap tidak memperdulikan kepentingan nasional yang lebih besar. Karena alasan kepentingan nasional dianggap lebih penting maka pengingkaran terkait dengan hak-hak individu diperbolehkan, serta sering kali adanya campur tangan pihak-pihak yang memiliki kepentingan sehingga hak-hak individu masyarakat sering kali dilanggar untuk memenuhi hasrat tersendiri.

Masyarakat adat sebagai kesatuan masyarakat hukum yang didalamnya terkandung hak hukum serta kewajiban hukum yang timbal balik antara kesatuan masyarakat adat dengan lingkungan sekitarnya dan juga dengan Negara. Perlindungan, penghormatan, dan pengakuan terhadap masyarakat adat berdasarkan asas keadilan bahwa masyarakat adat seharusnya mendapat perlakuan yang setara oleh Negara. Perlakuan terhadap masyarakat adat seharusnya setara seperti masyarakat pada umumnya. Hak-hak yang dimiliki masyarakat adat harus dilindungi, diakui, dan dihormati keberadaannya ${ }^{16}$. Dalam kenyataannya masyarakat adat sering kali mendapatkan perlakuan yang mengkonotasikan bahwa masyarakat adat adalah kelompok yang primitif dan menutup diri serta menolak kemajuan zaman yang berkembang, sehingga nilai-nilai serta norma yang dimiliki oleh masyarakat adat semakin pudar akibat perkembangan zaman. Oleh karena dibutuhkan peran penting Negara sebagai pemegang kewajiban perlindungan HAM agar tetap terjaganya eksistensi masyarakat adat dan sebagai wujud Negara hukum yang mengakui kehadiran hak asasi manusia.

Negara-negara dunia telah mengakui adanya hak warga negaranya sebagai wujud hak asasi manusia, di Indonesia dalam Undang-Undang Nomor 39 Tahun 1999 Tentang Hak Asasi Manusia, yaitu

"Seperangkat hak yang melekat pada hakikat dan keberadaan manusia sebagai makhluk tuhan Yang Maha Esa dan merupakan anugerah-Nya yang wajib dihormati, dijunjung tinggi dan dilindungi oleh Negara, hukum, pemerintah, dan setiap orang demi kehormatan serta perlindungan harkat dan martabat manusia”.

Secara filosofis HAM dimaksudkan untuk melindungi individu sebagai kodrat manusia dari tindakan sewenang-wenang oleh pihak penguasa. Dari segi historis kemunculan HAM merupakan akibat dari tindakan sewenang-wenang yang dilakukan oleh penguasa. Dalam perkembangannya konsepsi HAM dipengaruhi oleh berbagai faktor lainnya seperti filsafat, ideologi, agama, budaya, dan sebagainya. Secara substansial HAM lahir dari adanya tujuan untuk mencegah terjadinya penyalahgunaan kekuasaan (abuse of power) dari pihak penguasa sehingga hakikat dari HAM sendiri adalah hadir untuk melindungi harkat dan martabat sebagai manusia. Penguasa sebagai pihak yang memiliki kekuasaan serta kewenangan oleh karena itu dalam hal kewajiban untuk melindungi HAM dibebankan kepada pihak penguasa. Setiap individiu memiliki HAM, tetapi diatur dan dibatasi oleh hukum yang dibuat penguasa agar tidak saling bersinggungan ${ }^{17}$.

Pembangunan infrastruktur juga dikenal konsepsi mengenai HAM Pada Deklarasi Hak Atas Pembangunan (diterima oleh Majelis Umum PBB lewat Resolusi No. 41/128, pada 4 Desember 1986) menyatakan bahwa hak atas pembangunan adalah hak yang tidak bisa

16 Rosyada, A., Warassih, E., \& Herawati, R. (2018). "Perlindungan Konstitusional Terhadap Kesatuan Masyarakat Hukum Adat Dalam Mewujudkan Keadilan Sosial”, Kanun Jurnal Ilmu Hukum, 20 (1): 1-22 , h. 3

17 Sujatmoko, A. (2015). Hukum HAM dan Hukum Humaniter, Jakarta: Raja Grafindo Persada, h. 9-11 
dicabut (an inalienable right) dengan dasar bahwa setiap manusia berhak untuk berkontribusi, berpartisipasi, serta menikmati pembangunan ekonomi, sosial, politik, dan budaya. Keberadaan hak atas pembangunan juga ditegaskan dalam Deklarasi Wina dan Program Aksi Tahun 1993 melalui konsensus ${ }^{18}$. Sebagai suatu hak yang tidak bisa dicabut (an inalienable right) dalam hal pembangunan infrastruktur harus bisa terpenuhi secara maksimal bagi seluruh lapisan masyarakat, termasuk masyarakat adat. Dalam hal pembangunan infrastruktur harus bisa menjamin terpenuhinya unsur-unsur HAM secara nyata. Prinsip-prinsip mengenai HAM terdapat di hampir semua perjanjian internasional dan diaplikasikan ke dalam hak-hak yang lebih luas. Seperti prinsip kesetaraan, pelarangan, diskriminasi, dan kewajiban positif yang dibebankan kepada setiap Negara digunakan untuk melindungi hak-hak tertentu ${ }^{19}$.

Konsepsi gagasan mengenai pembangunan infrastruktur yang berlandaskan HAM dibangun atas dasar kesetaraan. Prinsip kesetaraan menekankan bahwa manusia berkedudukan setara menyangkut harkat dan martabatnya itu melekat pada diri setiap manusia, tidak terkecuali dengan masyarakat adat haruslah dianggap berkedudukan setara tanpa meilhat ras, suku, agama, warna kulit serta budaya yang berbeda. Kesetaraan mensyaratkan adanya perlakuan yang setara pada situasi yang sama haruslah diperlakukan sama, serta dalam situasi yang berbeda diperlakukan berbeda pula dengan berbagai pertimbangan serta perdebatan dilihat dari eksistensi masyarakat adat yang terkandung dalam Pasal 18B ayat 2 UUD 1945. Prinsip HAM selanjutnya yang harus diterapkan dalam pembangunan infrastruktur adalah prinsip mengenai pelarangan diskriminasi. Pelarangan diskriminasi merupakan salah satu hal penting dalam prinsip kesetaraan. UDHR menyebutkan beberapa alasan diskriminasi, seperti ras, warna kulit, agama, bahasa, jenis kelamin, pendapat politik atau opini lainnya, kepemilikan atas suatu benda, kebangsaan atau nasionalitas, kelahiran atau status lainnya ${ }^{20}$. Sebagai pemegang kewajiban atas HAM yaitu untuk melindungi hak-hak maka dalam hal pembangunan infrastruktur tidak boleh terjadi diskriminasi terhadap masyarakat adat.

Prinsip HAM selanjutnya adalah mengenai kewajiban positif yang dibebankan kepada setiap Negara untuk melindungi hak-hak tertentu. Negara dalam hal ini wajib untuk melindungi hak-hak masyarakat adat karena pada prinsipnya dalam hukum HAM, Negara atau pemerintah memiliki kedudukan sebagai pemangku kewajiban (duty bearer) dan individu-individu yang berdiam di wilayah juridiksinya sebagai pemegang hak (right bolder). Kewajiban yang wajib di emban Negara adalah kewajiban untuk menghormati (to respect), kewajiban untuk memenuhi (to fulfill), dan kewajiban untuk melindungi (to protect) HAM bagi setiap warga negaranya. Setiap Negara wajib menjamin pelaksanaan HAM bagi setiap warga negaranya, kewajiban yang dilaksanakan oleh Negara dalam hal mengambil langkahlangkah dalam bidang legislatif, administratif, yudisial, serta praktis dalam bidang social, ekonomi, politik, maupun bidang lain untuk mewujudkan jaminan hukum bagi warga negaranya ${ }^{21}$.

Pendekatan berbasis HAM membawa proses pembangunan infrastruktur ke arah yang lebih baik, lebih memperhatikan dampak yang terjadi, efektif, serta rasional untuk mewujudkan Negara yang bertanggung jawab sebagai pemangku kewajiban HAM atas

18 Pusat Penelitian dan Pengembangan Hak-hak Ekonomi, Sosial, dan Budaya (Indonesia). (2013). Aplikasi Analisis Dampak HAM Mendukung Pembangunan Berkelanjutan di Provinsi Kalimantan Selatan, Banjarmasin: Alumni, h. 10

19 Ibid, h. 11

20 Sujatmoko, A. Op. Cit., h. 12

21 Rahayu, R. (2012). Hukum Hak Asasi Manusia, Semarang: Badan Penerbit Universitas Diponegoro, h. 60 
pembangunan. Salah satu konsep yang sesuai atas HAM dalam konteks pembangunan infrastruktur adalah Free Prior Informed and Consent (FPIC), yang memiliki pengertian bahwa masyarakat secara umumnya berhak atas informasi (informed) sebelum (prior) dalam program pembangunan yang akan berdiri di wilayah mereka. Berdasarkan informasi tersebut masyarakat adat dapat bebas untuk menerima atau menolak (consent) tanpa adanya tekanan apapun (free), dengan kata lain masyarakat hukum adat dapat memutuskan apakah pembangunan infrasruktur yang berdiri di wilayah mereka boleh atau tidak untuk dilaksanakan. FPIC sangat penting dilakukan untuk menghentikan berbagai macam tindakan pelanggaran HAM akibat dari pemaksaan dalam hal pembangunan tanpa adanya perundingan terlebih dahulu yang dapat merugikan hak-hak masyarakat hukum adat. ${ }^{22}$

Peraturan perundang-undangan di Indonesia belum mengatur FPIC, tetapi terdapat beberapa hukum internasional yang dianggap menjamin atas hak FPIC dan diantaranya telah diratifikasi di Indonesia mencakup:

a) Kovenan Internasional tentang Hak-Hak Sipil dan Politik

b) Kovenan Internasioanl tentang Hak-Hak Ekonomi, Sosial, dan Budaya

c) Konvensi tentang penghapusan semua bentuk diskriminasi rasial

d) Hak ini secara tegas dicantumkan dalam naskah Deklarasi Perserikatan BangsaBangsa tentang hak-hak masyarakat adat

e) Konvensi Organisasi Buruh Internasional (ILO) No.169 tentang masyarakat adat dan suku bangsa

f) Konvensi tentang keberagaman hayati.

Beberapa Hukum Internasional diatas menunjukkan bahwa FPIC telah diterima secara luas sebagai suatu cara berbasis HAM dalam melakukan usaha di berbagai sektor ${ }^{23}$. FPIC atau bisa disebut Persetujuan atas dasar informasi di awal tanpa ada paksaan mengacu pada prinsip bahwa masyarakat hukum adat memiliki hak untuk memberikan atau menolak persetujuan yang dapat mempengaruhi mereka terutama dalam wilayah, tanah, dan sumber daya alam tradisional yang mereka miliki. Prinsip ini terkait dengan hak masyarakat hukum adat terkait dengan hak untuk menerima atau menolak proyek pembangunan infrastruktur yang dibangun dalam wilayah mereka (free, prior, and informed consent). Prinsip persetujuan atas dasar informasi di awal tanpa ada paksaan (FPIC) menegaskan bahwa masyarakat hukum adat mempunyai hak secara bebas untuk bisa menolak ataupun menerima rencana pembangunan infrastruktur di wilayah mereka atas dasar informasi yang lengkap dan terperinci disampaikan atau diperoleh masyarakaat hukum adat sejak sebelum rencana pembangunan infrastruktur ${ }^{24}$.

Terkait dengan pembangunan infrastruktur setiap pihak yang menyelenggarakan wajib untuk memberikan informasi sedetail mungkin dan lengkap terkait dengan segala informasi tentang proses pembangunan infrastruktur dan dampak baik dan buruk yang bisa terjadi terkait dengan proses pembangunan yang terjadi, setelah informasi didapatkan oleh masyarakat hukum adat maka diperlukan waktu bagi masyarakat hukum adat untuk bisa mendiskusikan bersama menurut cara adat mereka serta masyarakat hukum adat wajib untuk mendapatkan bantuan dari beberapa pihak agar informasi yang disampaikan terkait proses pembangunan infrastruktur ini bisa tersampaikan secara penuh karena masyarakat adat yang memiliki perbedaan terkait dengan bahasa dan kebiasaan adat yang mereka percaya.

22 Colchester, M. (2006). Panduan Bagi Para Aktivis: Free, Prior, Informed, Consent (FPIC), Statford: Forest Peoples Programme dan Pengurus Besar Aman, h.3

${ }^{23}$ Ibid, h.15

24 Salinding, M. B. (2019). "Prinsip Hukum Pertambangan Mineral dan Batubara yag Berpihak kepada Masyarakat Hukum Adat”, Journal Konstitusi, 16 (1): 149-169, h. 165-166 
Persetujuan atas dasar informasi di awal tanpa ada paksaan harus ada sebelum pemerintah, investor, dan pihak perusahaan melakukan rencana pembangunan infrastruktur di wilayah masyarakat hukum adat. Hal tersebut harus dipenuhi sesuai dengan amanat pasal 18B ayat (2) Undang-Undang Dasar 1945 yang merupakan pengakuan dan perlindungan atas masyarakat hukum adat.Pengakuan tersebut termasuk kedalam pengakuan terkait dengan hukum yang hidup di masyarakat atau yang dikenal sebagai living law yang berasal dari kebiasaan-kebiasaan yang sudah ada sejak dulu hingga sekarang dan dianggap sebagai hukum yang hidup di masyarakat, oleh karena itu pemerintah dalam pembangunan infrastruktur haruslah memperhatikan hak-hak serta hukum yang hidup di masyarakat sebagai wujud pembangunan infrastruktur yang memperhatikan aspek HAM. Prinsip pembangunan yang memperhatikan aspek HAM haruslah memposisikan masyararakat hukum adat sebagai subjek pembangunan dan bukan sebagai objek pembangunan.

\section{P E N U T U P}

Berdasarkan uraian yang disebutkan di atas, dapat disimpulkan bahwa pembangunan infrastruktur sebagai salah satu penggerak roda perekonomian bangsa dengan tujuan untuk mensejahterakan masyarakat pada kenyatannya banyak sekali konflik yang terjadi terkait dengan lahan antara masyarakat hukum adat dengan pihak pemerintah. Dilematis muncul terkait dengan kepentingan nasional atau hak-hak masyarakat hukum adat yang diakui keberadaannya selama tidak mengganggu kepentingan bangsa dan perundang-undangan. Bahwasannya hak-hak masyarakat hukum adat dapat dipinggirkan terkait dengan kepentingan nasional, oleh karena itu dibutuhkan peran aktif pemerintah untuk menyelesaikan permasalahan ini tanpa merugikan suatu pihak dan tidak terjadi kasus pelanggaran HAM di Indonesia terkait dengan pembangunan infrastruktur. Aarah pembangunan infrastruktur terkait dengan HAM maka dalam hal pembangunan infrastruktur haruslah berlandaskan HAM, sesuai dengan prinsip yang tertuang dalam HAM sebagai wujud pertanggung jawaban Negara sebagai pemangku kewajiban perlindungan HAM masyarakat hukum adat karena HAM adalah hak kodrat setiap manusia yang tidak dapat dicabut oleh siapapun.Peran pemerintah dibutuhkan terkait dengan proses pembangunan infrastruktur melakukan komunikasi serta memberikan informasi terkait dengan jalannya seluruh proses pembangunan infrastruktur agar terwujudnya prinsip FPIC (Free, Prior, Informed, Consent).

\section{DAFTAR PUSTAKA}

\section{Jurnal}

[1] Agus, A. A. (2017). Eksistensi Masyarakat Adat Dalam Kerangka Negara Hukum DiIndonesia. Jurnal Sosialisasi. 5-15.

[2] Hetharie, Y. (2019). Perjanjian Nominee sebagai Sarana Penguasaan Hak Milik atas Tanah oleh Warga Negara Asing (WNA) Menurut Kitab Undang-Undang Hukum Perdata, SASI, 25 (1): 27-36. DOI: https://doi.org/10.47268/sasi.v25i1.147

[3] Ikbal, I. (2015). Prinsip Free and Prior Informed Consent Terhadap Perlindungan Masyarakat Adat Atas Tanah Dalam Perspektif Hukum Hak Asasi Manusia Internasional. Fiat Justisia, 6 (3): 1-16.

[4] Laturette, A. I. (2016). Penyelesaian Sengketa Hak Atas Tanah Masyarakat Hukum Adat, SASI, 22 (2) : 52-66. DOI: https://doi.org/10.47268/sasi.v22i2.168.

[5] Rosyada, A., Warassih, E., \& Herawati, R. (2018). Perlindungan Konstitusional terhadap Kesatuan Masyarakat Hukum Adat dalam Mewujudkan Keadilan 
Sosial. Kanun: Jurnal Ilmu Hukum, 20 (1): 1-22.

[6] Salinding, M. B. (2019). "Prinsip Hukum Pertambangan Mineral dan Batubara yang Berpihak Kepada Masyarakat Hukum Adat”. Jurnal Konstitusi, 16 (1): 149-169

\section{Buku}

[7] Colchester, M. (2006). Panduan Bagi Para Aktivis: Free, Prior, Informed, Consent (FPIC), Statford: Forest Peoples Programme dan Pengurus Besar Aman.

[8] Isfardiyana, S. H. (2018). Hukum Adat. Yogyakarta: UII Press.

[9] Kusumaatmadja, M. (2003). Konsepsi Hukum Negara Nusantara pada Konferensi Hukum Laut. Bandung: Alumni.

[10] Marzuki, P. M. (2005). Penelitian Hukum, Jakarta: Media Group.

[11] Pusat Penelitian dan Pengembangan Hak-hak Ekonomi, Sosial, dan Budaya (Indonesia). (2013). Aplikasi Analisis Dampak HAM Mendukung Pembangunan Berkelanjutan di Provinsi Kalimantan Selatan. Banjarmasin: Alumni.

[12] Rahayu, R. (2012). Hukum Hak Asasi Manusia. Semarang: Badan Penerbit Universitas Diponegoro.

[13] Soekanto, S. (2016). Hukum Adat Indonesia, Jakarta: Rajawali Pers.

[14] Sujatmoko, A. (2015). Hukum HAM dan Hukum Humaniter. Jakarta: Raja Grafindo Persada.

\section{Online/World Wide Web}

[15] Novelino, A. (2019). Ribuan Orang Masyarakat Adat Jadi Korban Konflik Agraria. Retrieved from https://www.cnnindonesia.com/nasional/20190117042203-12361437/ribuan-orang-masyarakat-adat-jadi-korban-konflik-agraria.

[16] Ravelo, C. (2019). Sengketa Tanah Adat, Warga Dayak Meratus Demo DPRD Tanah Bumbu. Retrieved from https://nasional.tempo.co/read/869075/sengketa-tanah-adatwarga-dayak-meratusdemo-dprd-tanah-bumbu/full\&view $=$ ok.

[17] Yakur, A.S. (2019). Sengketa Agraria Meningkat di Duga Nampak Pembangunan Infrastruktur yang Masif. from https://www.hidayatullah.com/berita/nasional/read/2018/01/24/133768/sengketaagraria-meningkat-diduga-dampak-pembangunan-infrastruktur-masif.html.

[18] Zuhra, W. U. N. (2016). Proyek Infrastruktur Jokowi Biang Konflik Agraria. Retrieved from https://tirto.id/proyek-infrastruktur-jokowi-jadi-biang-konflik-agraria-b5yx. 